This is an EarthArXiv preprint, accepted by the Journal of Geography in Higher Education. Visit www.tandfonline.com/toc/cjgh20/current for the published version.

Learning by Doing: Enhancing Hydrology Lectures with Individual Fieldwork Projects

by A. F. Van Loon, School of Geography, Earth and Environmental Sciences, University of Birmingham, UK, Email: a.f.vanloon@bham.ac.uk 


\title{
Learning by Doing: Enhancing Hydrology Lectures with Individual Fieldwork Projects
}

\author{
A. F. Van Loon ${ }^{\mathrm{a}}$ \\ ${ }^{a}$ School of Geography, Earth and Environmental Sciences, University of Birmingham, UK
}

\begin{abstract}
ARTICLE HISTORY
Compiled March 19, 2019

ABSTRACT

Hydrology teaching deals with processes happening outside the classroom, which calls for active-learning methods to complement lectures. In a geography undergraduate course, new teaching methods and assessment were designed, in which students investigated a river of their choice by completing homework tasks and presenting their results on a poster. During a 3-year implementation process, the changes were evaluated using a combination of formal and informal student and lecturer feedback. Students mentioned that they enjoyed doing the project and that it helped their understanding of theory, their research skills, and their ability to select, organise and present information. Questionnaire results showed that, over the implementation period, students' perceived value of homework increased strongly, while their perceived value of lectures remained high. In informal feedback, students noted that they enjoyed learning about where they live, preferred doing the projects individually and seeing each other's projects, and spent more time on the coursework when assessed. When looking back in interviews, students commented that the projects had prepared them well for their dissertation and summer job. The advantage of using homework-based projects complementing lectures is the strong link between theory and practice, which could be further enhanced by discussing the homework in the lectures.
\end{abstract}

\section{KEYWORDS}

education; undergraduate; physical geography; hydrology; active learning; student-centred teaching

\section{Introduction}

Hydrology studies earth processes, which are happening outside the classroom. Traditionally, two approaches have been used for teaching these processes to geography students: i) lectures in which the theory is taught and examples of real world places and cases are used to bring the outside world into the classroom, and ii) excursions and fieldwork in which students explore the outside world guided by a teacher. Both are crucial in student learning and engagement, but they are not always well linked (Oliver, Leader, \& Kettridge, 2018). For example, often excursions are organised in separate courses and outside of term time. Several scholars have suggested that integration of lectures and field courses would be beneficial to student learning (e.g. Gleeson, Allen, \& Ferguson, 2012). Besides some examples integrating field and lab experiments (Noll, 2003; Trop, Krockover, \& Ridgway, 2000), there are no reports in

CONTACT A. F. Van Loon. Email: a.f.vanloon@bham.ac.uk 
literature on the integration of lectures and fieldwork in hydrology. In this study, I present the implementation of individual homework-based student projects in a geography undergraduate module ${ }^{1}$.

Another drawback of both these traditional teaching methods (lectures and excursions) is that they are lecturer-centred and often passive, while ample research suggests that active and student-centred teaching increases student learning (Prince \& Felder, 2006; Thompson, Ngambeki, Troch, Sivapalan, \& Evangelou, 2012). There are very few studies that investigate student-centred approaches in hydrology teaching, especially in the undergraduate (Thompson et al., 2012). The few that do, do not evaluate their effectiveness (Elshorbagy, 2005) or only by using their own experience and observations (Rustum, 2018), only for one year (Arthurs \& Templeton, 2009), or only by using standard official module evaluations and marks (e.g., Hakoun, Mazzilli, Pistre, \& Jourde, 2013). In this study, I evaluate the merits of a specific example of student-centred active learning in hydrology over an implementation period of three years, complementing official module evaluation data and student marks with informal student feedback, results from a targeted questionnaire, and interviews with students and lecturers.

In Section 2, hydrology education is placed in the broader literature on education in geography and engineering and some recent developments are highlighted. Especially active learning approaches, problem- and project-based learning, and innovative assessment in these fields are discussed. In Section 3, the case study, i.e. the 2nd year Geography undergraduate module 'Hydroclimatology' at the University of Birmingham (UK), is introduced and the changes in teaching methods and assessment that were implemented are described. In Section 4, the methodology is presented that is used to evaluate the effects of introducing student-centred projects and assessment on student engagement, understanding, and marks. The results of that evaluation are presented in Section 5 and discussed in Section 6, by linking them back to the educational theory. And finally, in Section 7, the study is summarised and some concluding remarks are added.

\section{Theory}

\subsection{Hydrology education within geography and engineering}

Hydrology is an applied research field in the natural sciences studying the distribution and movement of water in the environment. Hydrology teaching is done in (physical) geography or (civil) engineering programmes, or sometimes in earth sciences programmes. Educational literature specifically for hydrology is limited (Thompson et al., 2012). This section therefore draws from the wider educational literature, mainly from the fields of geography and engineering.

In hydrology, like in other physical geography topics, 'systems thinking' is required to understand complex earth processes (Kastens \& Manduca, 2012; King, O'Donnell, \& Caylor, 2012; Ruddell \& Wagener, 2013; Wagener et al., 2010). Graduates need to have theoretical knowledge, ability to develop and test conceptual models, experience in data gathering, analysis and interpretation, and communication skills (Pathirana, Koster, Jong, \& Uhlenbrook, 2012; Thompson et al., 2012). Additionally, it is important that they develop positive feelings for the subject, so that they get excited to learn and explore more (Thompson et al., 2012).

\footnotetext{
${ }^{1} \mathrm{~A}$ module is a unit of teaching or course in the UK higher education system.
} 
Much of the literature on stimulating system thinking in hydrology education is on the scale of the whole curriculum or even hydrology education in general (e.g., King et al., 2012; Ruddell \& Wagener, 2013; Wagener et al., 2010), but the question for hydrology lecturers is how we can apply this information in the daily practice of our teaching (Thompson et al., 2012). Research has shown that those students that achieved increased system thinking were the ones that had been highly involved in 'knowledge integration activities' during inquiry-based learning, both in the classroom and in the field (e.g., Assaraf \& Orion, 2005; Cutrim, Rudge, Kits, Mitchell, \& Nogueira, 2006).

Effective hydrology teaching should include 'inductive' teaching methods, which encompasses a range of teaching methods, including inquiry-based learning, problemand project-based learning, case-based teaching, and discovery learning (Prince \& Felder, 2006). The overarching principle is that these are more student-centered than 'deductive' teaching methods and that they require some degree of responsibility and active engagement of the student (Prince \& Felder, 2006).

Inductive teaching increases deep learning, which has been found to result in 'greater educational gains, higher grades, and greater satisfaction' amongst students (Laird, Shoup, Kuh, \& Schwarz, 2008). Laird et al. (2008) also found that inductive teaching and active learning are less common in the 'hard' disciplines (natual sciences) than in the 'soft' disciplines (social sciences). Several scholars have argued for a change from lecturer-centred to student-centred teaching methods in hydrology (Gleeson et al., 2012; Pathirana et al., 2012; Thompson et al., 2012). In lecturer-centred teaching methods the lecturer is an 'expert teacher', with students listening, reading and applying knowledge to specific problems (Pathirana et al., 2012). In contrast, in student-centred teaching methods the lecturer acts as 'facilitator' with students having a certain degree of autonomy over their learning (Pathirana et al., 2012).

\subsection{Active learning in lectures and field teaching in hydrology}

Currently, most university undergraduate teaching is still done in lectures (Gibbs, 2014), especially in hydrology that inherited a strongly lecturer-centred educational tradition (Pathirana et al., 2012; Rustum, 2018; Thompson et al., 2012). Engaging lectures can be a good way to transfer basic knowledge to large groups and they are regarded as time-efficient. However, learning from lectures only is generally poor (Handelsman, Miller, \& Pfund, 2007) and interactive in-class activities are needed to let students engage with the material (Gibbs, 2014; Handelsman et al., 2007). Roebber (2005), for example, found a mismatch between student learning styles and teaching methods in an undergraduate meteorology course and recommend the use of case study examples, graphical representations of theory, in-class participation, group work, and pointing out connections between theory and everyday life. Cutrim et al. (2006) implemented a range of inquiry-based learning techniques in undergraduate meteorology lectures to encourage engagement and deeper understanding and found that student learning was influenced positively. And Buckley, Bain, Luginbuhl, and Dyer (2004) added discussion sessions to a large lecture-based undergraduate module in geography.

It is crucial that physical geography students experience the real world, not only because it increases their process understanding but also because it increases their enthusiasm for the subject. Therefore, excursions and field courses are widely used in geography and are regarded as a crucial mode of teaching (Fuller, Edmondson, France, Higgitt, \& Ratinen, 2006; Kent, Gilbertson, \& Hunt, 1997; Krakowka, 2012). 
To avoid the high financial and time investment some researchers have experimented with innovative methods such as mobile technologies, virtual field tours, and campusbased fieldwork (Kingston et al., 2012; Krakowka, 2012; Oliver et al., 2018; Stainfield, Fisher, Ford, \& Solem, 2000), generally with positive results. Field teaching can be both lecturer-centred, student-centred or a combination of both. Some recent studies have shown the advantages of completely student-led field courses (Coe \& Smyth, 2010; Pawson \& Teather, 2002), while others found that completely student-centred field courses run the risk of perpetuating misconceptions (Fuller, Rawlinson, \& Bevan, 2000) and putting all responsibility on the student (Thompson et al., 2012).

In some cases, students reported difficulty in achieving deeper understanding when doing fieldwork (Hill \& Woodland, 2002) and students learned more when they received some lecturer explanation whilst doing the fieldwork (Fuller et al., 2000). It is therefore important that fieldwork is coupled to the theory in some way, via lecturer explanation or reading. One option is to supplement lectures with homework, which enhances learning as an active process (Arthurs \& Templeton, 2009; Thompson et al., 2012) and stimulates more elements of Kolbs circle of concrete experience (feeling/sensing), reflective observation (watching), abstract conceptualisation (thinking), active experimentation (doing) (Kolb, 1984). Homework can be used to develop comfort and empowerment, to improve knowledge and conceptual understanding, and to link science to everyday life (Arthurs \& Templeton, 2009). To my knowledge there are no studies on the effectiveness of using homework to complement hydrology lectures.

\subsection{Problem- and project-based learning}

Problem-based learning has been suggested as an effective strategy for more active learning in hydrology (Thompson et al., 2012). Problem-based learning is a 'teaching technique that uses problem-solving as the basis for student learning' (Beringer, 2007). This approach is used in hydrology teaching, especially when it is part of an engineering programme (Thompson et al., 2012), but also in geography (Spronken-Smith, 2005). An application of problem-based learning in hydrology is using computer models to investigate scenarios that could occur in reality (e.g., Aghakouchak \& Habib, 2010; Elshorbagy, 2005; Seibert \& Vis, 2012). This develops problem-solving skills, but is often still quite lecturer-focused, with the lecturer describing the steps to be taken and the scenarios to be analysed. Goris and Dyrenfurth (2012) found that students learn how to follow specific guidelines, but are often unable to explain why they followed those guidelines and are unable to apply the same concepts to a new problem. To develop the critical thinking skills needed in a complex and uncertain world (systems thinking), students need more opportunities to apply knowledge in new contexts and integrate previous and new knowledge (Thompson et al., 2012; Woods, Felder, Rugarcia, \& Stice, 2000).

Project-based learning focuses on application of knowledge in longer projects, for example related to problem-solving for industry partners (Mills, Treagust, et al., 2003; Thompson et al., 2012). Project-based learning can be applied in lecturer-centred or student-centred way and it often uses case studies. Biggs (1999) recommends case study projects because they train 'application, research skills, and professional skills'. Several studies found that students appreciate and perform well if they can design and execute their own project (Kneale, 1996; Pawson \& Teather, 2002). Case studies are common in engineering education (Yadav, Shaver, \& Meckl, 2010) and other more applied science fields (Thompson et al., 2012). Studies have found that case-study learning increases 
student engagement (Hoag, Lillie, \& Hoppe, 2005; Yadav \& Beckerman, 2009), critical thinking, and problem-solving skills (Dochy, Segers, Van den Bossche, \& Gijbels, 2003; Henderson, Bellman, \& Furman, 1983). However, since case studies do not necessarily increase students' conceptual understanding (Yadav, Subedi, Lundeberg, \& Bunting, 2011), linking the case study based learning to theoretical learning, via reading or lectures, is needed.

Different options for case studies have been reported in literature. King et al. (2012) describe the benefits of case studies far from home in 'hydrology holiday destinations', that would stimulate students' curiosity and awareness of other relevant aspects, such as the effects of different culture, socio-economic situation, water infrastructure, and regulations of water use. With more and more internet resources and online open databases available, this is an increasingly feasible option (King et al., 2012). However, it negates the objective of using case studies to let students observe the real world outside the classroom and away from computer screens. Choosing a very local context that is 'personally familiar' to the student allows for reallife experience of the outside world (King et al., 2012). Another advantage of choosing a local case study in our case is that there is an abundance of data and information sources for the UK, such as apps for soil types and geology and realtime river discharge data for thousands of gauging stations across the UK (see Sect. 3.2).

Most examples of problem- and project-based learning in the literature are from group projects (e.g., Haigh \& Gold, 1993; Healey, Matthews, Livingstone, \& Foster, 1996; Kent et al., 1997; Spronken-Smith, 2005), with varying success. Group work can have many learning benefits if implemented well, but it can also create issues with group dynamics and assessment (Kent et al., 1997; Spronken-Smith, 2005). On the other side of the scale is 'discovery learning', in which students work alone with little guidance (Thompson et al., 2012). This gives the students ownership and responsibility for their own learning.

\subsection{Assessment}

If we want students to properly engage with active learning activities, such as case study projects and homework, they need to be assessed. Following Biggs' theory of constructive alignment (Biggs, 1996), the assessment needs to be in line with the teaching method used. For example, Gijbels, Dochy, Van den Bossche, and Segers (2005) found that problem-based learning had most positive results when the assessment focused on testing students' understanding of 'principles that link concepts'. With a move to more active learning, a move away from exams is needed (Gijbels et al., 2005). Gibbs and Simpson (2005) argue that coursework encourages higher quality learning than exams.

One option for assessment of active learning is using poster presentations. Hay and Thomas (1999) found that posters are used relatively infrequently in undergraduate programmes, but there seems to have been an increase in use recently. Benefits of poster assessment in undergraduate teaching mentioned in scientific literature are: stimulating learning, allowing for creativity, promoting skills of gathering, selecting, condensing and organising information, supporting visual learners (Hay \& Miller, 1992; Howard, 2015; Jarvis \& Cain, 2003; Kneale, 1996; Walker, 2005). From a lecturer perspective, posters also reduce marking time and make it easy to provide instant feedback (Jarvis \& Cain, 2003). Posters are also good for real world practice, because visual displays and short oral presentations are often used in the workplace (Race, 2014). 
This is an EarthArXiv preprint, accepted by the Journal of Geography in Higher

Education. 3 CASE STUDY "HYDROCLIMATOLOGY"

Table 1. Number of students registered and percentages in different categories. Geog = Geography, Env Science = Environmental Science, Geol/Phys Geog = Geology/Physical Geography

\begin{tabular}{|c|c|c|c|c|c|c|c|c|c|c|c|}
\hline \multirow[b]{2}{*}{ Year } & \multirow{2}{*}{$\begin{array}{l}\text { total } \\
\text { no. }\end{array}$} & \multicolumn{2}{|l|}{ gender } & \multicolumn{3}{|l|}{ age } & \multicolumn{5}{|c|}{ study programme } \\
\hline & & female & male & $19 y r$ & $20 y r$ & $\geq 21 \mathrm{yr}$ & $\begin{array}{l}\text { BSc } \\
\text { Geog }\end{array}$ & $\begin{array}{l}\text { BA } \\
\text { Geog }\end{array}$ & $\begin{array}{l}\text { BSc } \\
\text { Env } \\
\text { Science }\end{array}$ & $\begin{array}{l}\text { BSc } \\
\text { Geol/Phys } \\
\text { Geog }\end{array}$ & other \\
\hline $2015-16$ & 40 & $57 \%$ & $43 \%$ & $64 \%$ & $27 \%$ & $9 \%$ & $57 \%$ & $7 \%$ & $29 \%$ & $7 \%$ & $0 \%$ \\
\hline $2016-17$ & 60 & $62 \%$ & $38 \%$ & $65 \%$ & $27 \%$ & $8 \%$ & $50 \%$ & $7 \%$ & $28 \%$ & $10 \%$ & $5 \%$ \\
\hline $2017-18$ & 42 & $57 \%$ & $43 \%$ & $76 \%$ & $17 \%$ & $7 \%$ & $59 \%$ & $14 \%$ & $12 \%$ & $10 \%$ & $5 \%$ \\
\hline
\end{tabular}

Student-centred teaching approaches also benefit from the use of formative assessment (Biggs \& Tang, 2011; Kent et al., 1997). Peer evaluation has been found to be a useful tool in formative and summative assessment (Dochy, Segers, \& Sluijsmans, 1999; Hay \& Miller, 1992; Kent et al., 1997). If it is used in formative assessment, peer evaluation becomes part of the learning process (Dochy et al., 1999).

\section{Case study "Hydroclimatology"}

\subsection{Module description}

'Hydroclimatology: climate and water' is an optional 2nd year undergraduate module in Physical Geography. The module consists of lectures on meteorology and hydrology by three different lecturers and runs over two semesters. It typically attracts between 40 and 60 students (Table 1), roughly $60 \%$ female and $40 \%$ male, mainly from the BSc/BA Geography, but also some from the BSc Environmental Science and BSc Geology / Physical Geography (Table 1).

In 2014-15, when I first taught on this course, there were only classical lectures. Students asked for homework and things to do to prepare for a lecture. The module's original assessment was a $100 \%$ essay-style exam, but students reported that they would prefer more coursework and that they found it very stressful that the entire mark was based on this one exam. As lecturers, we also noted that students would learn strategically for the exam by skipping some important but difficult material, that the exam setup disadvantaged students who were not good at writing essays, and that students failed to integrate the topics of meteorology and hydrology.

One of the learning outcomes of the module is that the students are able to: 'Apply the knowledge and skills gained in the analysis of atmospheric and water resource management problems', but this was not really trained or tested with the current teaching setup. We wanted the students to learn to integrate, to link climate to hydrology, link theory to practice, link the classroom to the outside world.

We therefore designed a coursework assignment based on individual projects, in which students would need to research the weather and water of a region of their choice, using field observations, secondary data, and internet and app-based resources. The project would be based on practical homework tasks in between lectures, spreading the workload for the students, reducing burden during the exam period and allowing them more opportunities for feedback, because they start engaging with material during teaching semesters. This would also allow the lecturers to get a better feel for how the students are doing during the teaching semester. 


\subsection{Coursework assignment and practical homework tasks}

The overarching theme of the coursework was the relation between climate and water for a chosen region within the UK (see the assessment brief in Box 1). Students had to choose a case study catchment with enough data availability (minimum one discharge gauging station and one meteorological station with long-term data) and follow the weather situation and river flow during semester 1 and 2 . The precipitation and temperature data and weather charts for their study area could be obtained from the UK MetOffice or from citizen science data (both available online) and the river flow data from the National River Flow Archive (historical data) and from online platforms such as Gaugemap (recent data). From those data students had to select a week with an interesting event, for example a flood, a dry period, a heavy snow event. The students then had to explain the relationship between the weather and the river flow for that specific event in their case study region, using information about the region, e.g. geology, soil type, land use, climate, human interference, which they collected in the homework assignments in between the lectures. Examples of the homework assignments included:

- get information on the average climatic conditions for your study catchment, f.e. find out how much snow falls on average;

- calculate the correlation between historic precipitation and NAOI (North Atlantic Oscillation Index) time series;

- determine local soil type by taking a soil sample and doing the squeeze test or the jar test;

- do a simple infiltration experiment to determine soil permeability;

- investigate the geology and groundwater situation in your study catchment using the British Geological Survey 3D field geology app;

- photograph surface runoff when it rains in your catchment;

- get information on the land use characteristics and human activities in your study area from the National River Flow Archive catchment description, from Google Earth, and from your own observations;

- investigate historic flood and drought events that have occurred in your study catchment and find information on the causes and impacts of these events, for example by using news reports and drought index information.

\subsection{Implementation and assessment}

The changes were implemented gradually over a few years, because we needed to go through a formal approval process, which allowed for testing and tweaking. In 2015-16, we encouraged students to engage with the practical homework tasks, but these were not linked nor assessed. In 2016-17, the homework tasks were brought together into an individual research project that was assessed with an 3-minute poster presentation (50\% of total mark). We also introduced a formative assessment of a draft poster presentation in a peer-feedback session (see Box 1). In 2017-18, minor changes were done to the coursework guidance to focus the assignment more on explaining an event using only the information that is needed instead of having the students present all information they collected on the poster, and more time was allotted to the presentation ( 5 minutes). Also, specific marking criteria were designed for the coursework assignment (see Box 1).

We used e-posters (posters presented on a screen) instead of printed posters to avoid 
difficulties and costs of printing and to allow for the lecturers to see the posters in advance of the presentation session (when they are uploaded to the university system) to make marking easier during the presentations. The use of e-posters also opened up the possibility of sharing best practice examples (see Appendix Figure A1) with future students (as suggested by Race, 2014). During the poster session at the end of the second semester, students presented their poster to a small group of peers (10 students), one teaching assistant, and one lecturer / marker, and answered questions from students. Marks were moderated between the three markers by comparing and discussing average marks and range of marks.

We designed an optional formative assessment moment after the first semester, in which students could present a draft poster for which they would have done about half of the data gathering and analysis. This session allowed them to get peer-feedback on their project, on the draft poster, and on their oral presentation skills. In the summative poster session, markers completed feedback sheets for each student, which were distributed to students with their mark the day after the session, allowing students to use this information when preparing for the exam. Besides this individual feedback, generic oral feedback was provided to the whole class, both in the formative and summative assessment.

We think this redesigned assessment has a number of benefits compared to the previous setup of lectures and exam. The poster presentation assessment measures if students can apply the theory in their own case study outside the classroom; it has the potential to increase enthusiasm for the subject because students work on their own topic in their selected case study region; it forces students to only present the most important aspects of the research because space and time are limited; both the project and the poster format allow for creativity; it allows to distinguish between students who have done nothing, those who have done something but lack understanding, and those who have done things and understand the processes; and finally it is more inclusive, both for more visual learners and for international students (De Vita and Case, 2003).

Besides adding a coursework assessment, we also changed the exam (which now accounts for $50 \%$ of the total mark). The three essay-style questions, which the students could choose out of a total of nine questions, were replaced by ten short-answer questions, composed of several short sub-questions, which all had to be answered. An evaluation of the effect of changing the exam is, however, outside the scope of the current study and this will not be discussed further. 


\section{BOX 1: COURSEWORK ASSESSMENT BRIEF}

Poster presentation, including 5 min oral presentation explaining the most important points of your poster and 3 min of questions.

\section{Objectives:}

- apply knowledge outside the classroom;

- integrate your understanding of climate and water for a chosen region within the UK;

- explain a hydrological event from the meteorological conditions and catchment characteristics;

- select appropriate information for a poster;

- orally present your findings to a small audience with similar background (your peers).

\section{Preparation:}

- selecting a case study;

- collecting information: follow weather and river flow weekly during semesters, execute weekly homework tasks (including primary / secondary data collection \& analysis);

- analysing and selecting information: select which week you are going to discuss on your poster, select the relevant information that you need to explain the relation between river flow and the weather (see homework tasks for more information);

- preparing your poster: feel free to use the Powerpoint template that has been provided here and adapt it for your poster (see poster guidance for more information).

Pre-assessment feedback: formative in-class peer-feedback session in week 1 of Semester 2 , in which students discuss a draft poster showing their preliminary results from the first semester assignments (meteorology and climate) in small subgroups and get feedback with post-it notes on elements that work well and points that could be improved (both on content and presentation). It will also include a group discussion on the coursework.

\section{Marking criteria:}

0-20: not done anything, or poster and presentation contain nothing of value

20-40: did some of the tasks and has some information on poster and in presentation, but lacks understanding and cannot explain processes, fails to integrate the individual fieldwork with knowledge from lectures

40-50: did the tasks and is able to present the results on the poster, but some errors and misunderstandings, is missing obvious aspects of the relation between meteorology and hydrology, oral presentation is very basic (mainly reading out the information on the poster) and staying within lecture material

50-60: did the tasks correctly and is able to present the results on the poster, showing some understanding of processes, maybe missing some aspects or failing to see the bigger picture, stays quite close to lectures, able to explain important points in oral presentation

60-70: did tasks well and presents the results clearly and concisely on the poster, showing understanding of interaction between meteorology and hydrology, integrated the individual fieldwork with knowledge from lectures, oral presentation used to highlight interesting elements from the poster

70-80: has done the tasks very well and found a creative and convincing way to present the results on the poster, showing good understanding of interaction between meteorology and hydrology, and integrated the individual fieldwork with knowledge from lectures and literature, good oral presentation highlighting crucial elements from the poster

80-100: has done something extra (went beyond the tasks) to collect material that is presented very convincingly on the poster, showing excellent understanding outside lectures based on own research and additional reading, creative oral presentation that engages the listener and increases their understanding

Summative Assessment (50\% of final mark): session in week 10 of Semester 2. Posters have to be uploaded one day in advance.

Post-assessment feedback: generic feedback orally, individual feedback sheets returned before start of exam period. 


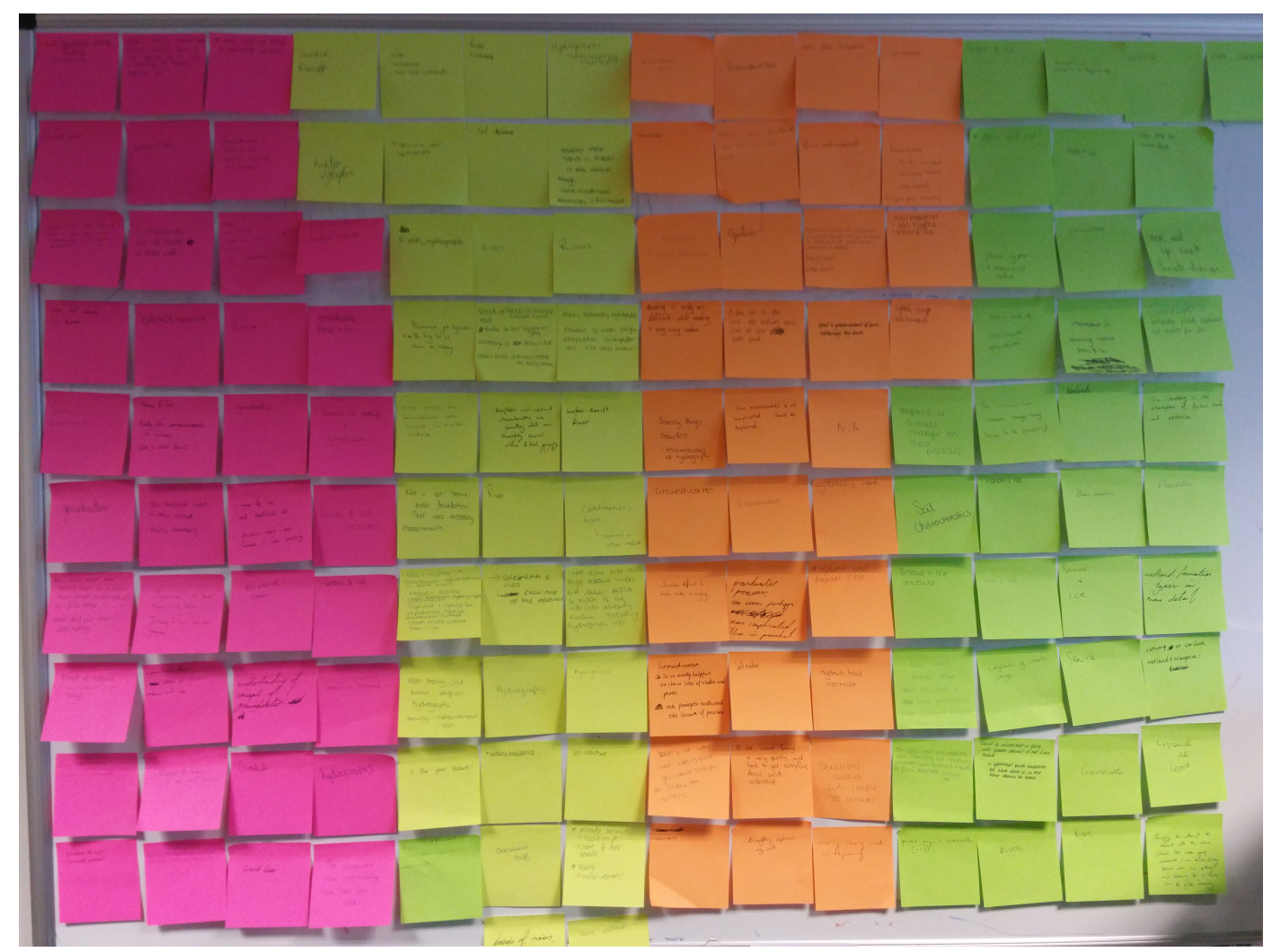

Figure 1. Example of informal feedback gathered with post-it notes from the students of 2016-17.

\section{Evaluation}

The gradual implementation of the changes in assessment allowed for evaluation of their effectiveness in different stages. Both student and lecturer feedback and student marks were analysed. Feedback from students was gathered in four ways:

(1) informal feedback during the semesters via post-it notes and oral feedback;

(2) official module feedback forms;

(3) a questionnaire;

(4) interviews with selected students.

The informal feedback was collected during the formative poster presentation session and during semester 2 (Figure 1). Because there were no specific questions or topics for the feedback, only some students provided qualitative comments on the coursework during this stage.

The official module feedback forms were completed on the last day of teaching, so the week before the poster presentation and two months before the exam (as is customary at the University of Birmingham). The form included several generic questions about the organisation of the module, teaching methods and materials, and questions about student engagement, and about lecturer inspiration and communication. For this paper only the relevant questions were used. Lecturers do not have access to the complete results of the official module evaluations, so only averages and ranges are reported here.

To get more specific feedback on the effectiveness of changes in teaching methods 
This is an EarthArXiv preprint, accepted by the Journal of Geography in Higher

Table 2. Number of students perticipating per evaluation type. Percentages calculated from totals in Table 1

\begin{tabular}{lllll}
\hline & \multicolumn{2}{l}{ participants questionnaire } & \multicolumn{2}{l}{ participants interviews } \\
\cline { 2 - 5 } Year & no. & $\%$ of total & no. & $\%$ of total \\
\hline $2015-16$ & 27 & $68 \%$ & - & - \\
$2016-17$ & 44 & $73 \%$ & 5 & $8 \%$ \\
$2017-18$ & 29 & $69 \%$ & 2 & $5 \%$ \\
\hline
\end{tabular}

and assessment I developed a questionnaire, in which students were asked to scale several teaching and feedback elements on a Likert scale, from 1 (strongly disagree) to 5 (strongly agree), on whether that element helped them understand and learn (see Appendix Figure B1). Students were also asked how much time they spent on the homework tasks and which elements they liked most and found most difficult (see Appendix Figure B2). This questionnaire was also done on the last day of teaching (before the poster presentation and the exam).

To gather student feedback after the poster presentations and to allow time for reflection and seeing the module in a broader perspective, interviews were done with students from the cohort of 2016-17 and 2017-18. These interviews were done in June 2018 , which is more than one year after the poster presentations and exam for the 2016-17 cohort and three months after the poster presentation and one month after the exam for the 2017-18 cohort. I selected the students for these interviews from my tutorial groups, so that they would feel comfortable sharing their opinion. Participation was voluntary and the students' consent for using anonymised quotes was obtained. It was also made clear to them that critical comments were allowed. Semi-structured interviews were used to give students the freedom to express their opinion and suggest topics for discussion (Drever, 1995). Students were asked to reflect on their individual coursework projects, on the link between the homework and the lectures, and on what they learned from the project. Additionally, students were asked what they thought of doing the work alone, instead of in a group, and whether they would recommend the module to next year's students.

The number of students returning the questionnaire was around $70 \%$ for each year (Table 2). The number of students interviewed was 5 to $8 \%$ (none from 2015-16). For practical reasons, the 2016-17 cohort were interviewed as a group, the 2017-18 cohort in two separate one-to-one interviews. The interviewees consisted of 5 male and 2 female students, mostly 19yr old when taking the module (one of 20yr old), and all of them doing the BSc/BA Geography. Except for gender, this seems to be a representative sample (Table 1 ).

Finally, the two other lecturers on the course were interviewed in July 2018, after the changes were implemented and evaluated, in a semi-structured interview with both lecturers together. They were asked to reflect on the individual fieldwork assessment, on changes in student engagement between the years, on comparing with group projects, and on changes they made to the lectures.

\section{Results}

\subsection{Time spent}

In the end-of-teaching questionnaire students reported an increase in time spent on the homework tasks over the years (Table 3). In 2015-16, when the homework was 
This is an EarthArXiv preprint, accepted by the Journal of Geography in Higher Education.

Table 3. Time spent on homework tasks as reported by students in the end-of-teaching questionnaire.

\begin{tabular}{lll}
\hline Year & Time spent on homework tasks & $\begin{array}{l}\text { Would / Should you have spent more time } \\
\text { (if the tasks were assessed)? }\end{array}$ \\
\hline $2015-16$ & $\begin{array}{l}\text { mostly 'not much', some 10-30 min per week, some } \\
\text { 1-2h a week }\end{array}$ & mostly 'much more', some 2-3h or 3-4h \\
$2016-17$ & $\begin{array}{l}\text { mostly 30 min - 1h per week, some 1-2h a week } \\
\text { mostly 1h per week, some 30 min a week, some 2h } \\
\text { a week, some 2-3h per week }\end{array}$ & yes 17, no 4, maybe 3 \\
& \\
\hline
\end{tabular}

a Question slightly different between years: 2015-16: "Would you have spent more time if the tasks were assessed?" 2016-17 and 2017-18: "Should you have spent more time?"

not assessed, student spent "not much" time on them. Only a few diligent students really did the tasks and devoted $1-2 \mathrm{~h}$ per week. In $2016-17$, students spent $30 \mathrm{~min}$ to 2 hours per week, in 2017-18 30 min to 3 hours per week. When I asked the 2015-16 students for questions or comments about the homework in the next class, there was only awkward silence, which gave me the impression that most had not done anything. In contrast, the 2016-17 and 2017-18 cohorts showed more response when asked for feedback about the homework.

In 2015-16 students indicated that they would spend "much more time" on the homework tasks if they would be assessed, but many overestimated the time they would spent compared to what the next cohort reported they spent when the homework was assessed. In 2016-17 and 2017-18, most students indicated that they should have spent more time. Many mentioned in the comments that they did not spend more time due to other pressures (essay deadlines for other modules, etc.).

\subsection{Marks}

The exam marks were similar between the years, with 2016-17 slightly lower than 2015-16 and 2017-18. That was the year that the new exam format (short-answer questions) was introduced and the students later mentioned that they had been unsure how to prepare for this format and that they had not had enough practice questions.

The average poster presentation marks were the same between the years, but the range was larger in 2017-18. All markers also gave the same mark on average for the students in their groups (maximum one point difference), so there was no marker bias. The range was slightly different between the markers, but during moderation all agreed on the marks given.

\subsection{Questionnaire}

Students found the Powerpoint slides and the explanation by a lecturer the most beneficial for their learning (Figure $2-1,2$ ). This was consistent throughout the

Table 4. Student marks in exam and coursework assessment. In 2017-18, there were two no-shows at the poster presentations. In 2016-17, there were no no-shows.

\begin{tabular}{lllllll}
\hline & \multicolumn{2}{l}{ Exam marks } & \multicolumn{3}{c}{ Poster presentation marks (without no-shows) } \\
\cline { 2 - 6 } Year & mean & $\min$ & $\max$ & mean & $\min$ & $\max$ \\
\hline $2015-16$ & 57 & 21 & 75 & - & - & - \\
$2016-17$ & 53 & 26 & 81 & 66 & 50 & 78 \\
$2017-18$ & 56 & 24 & 81 & 66 & 36 & 82 \\
\hline
\end{tabular}


This is an EarthArXiv preprint, accepted by the Journal of Geography in Higher

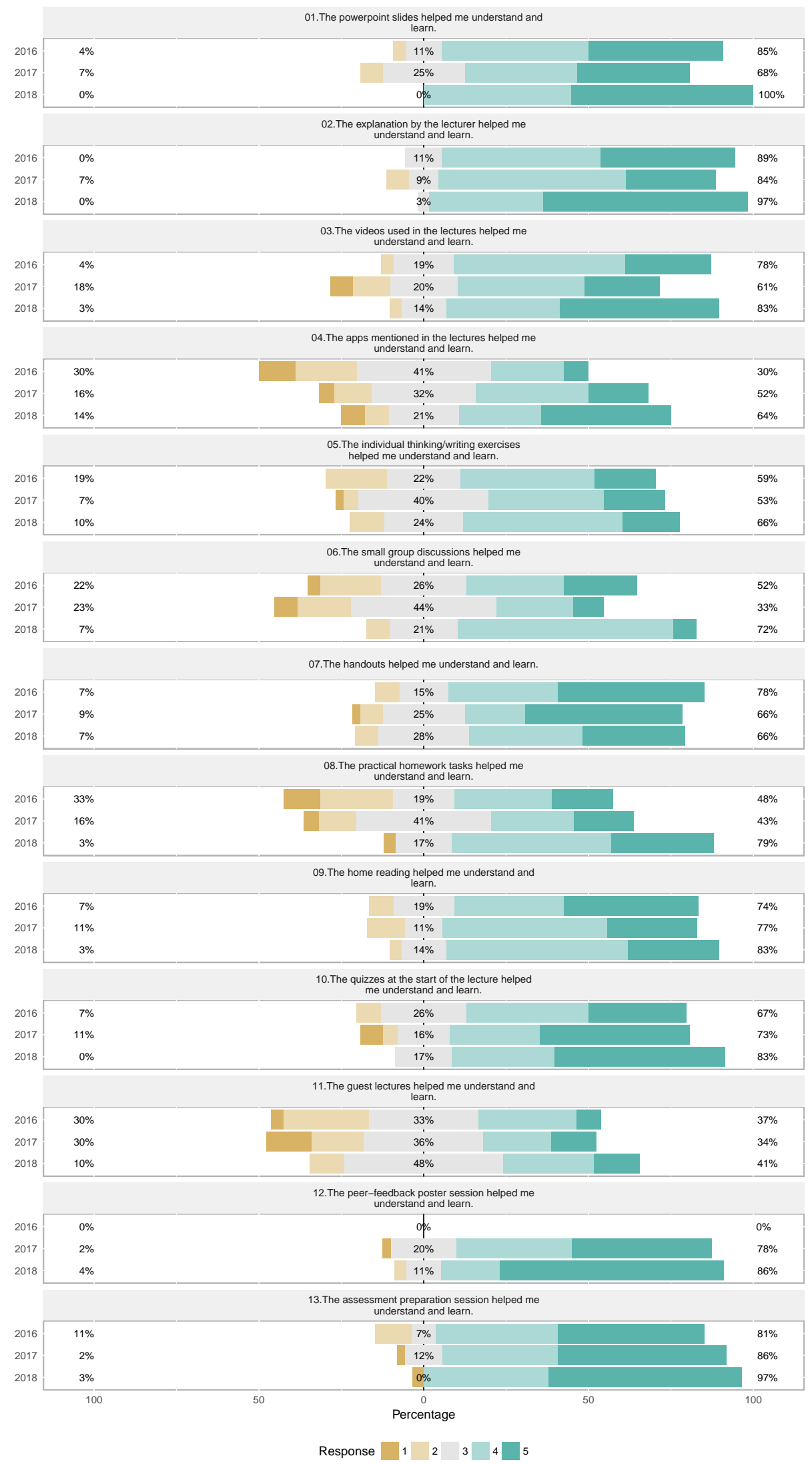

Figure 2. Results of the questionnaire on the various teaching materials introduced in the module, evaluated with a Likert scale: $1=$ strongly disagree, $2=$ disagree, $3=$ neutral, $4=$ agree, $5=$ strongly agree. 
This is an EarthArXiv preprint, accepted by the Journal of Geography in Higher

Education.

$5 \quad$ RESULTS

Table 5. Selected results from the official module feedback, obtained using a Likert scale: $1=$ strongly disagree, $2=$ disagree, $3=$ neutral, $4=$ agree, $5=$ strongly agree.

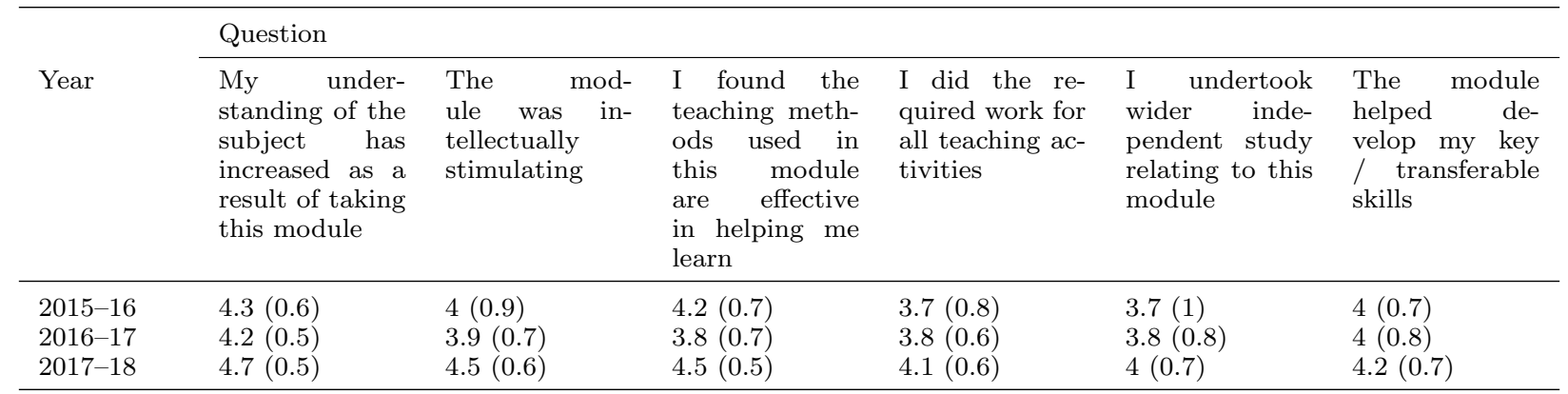

years, with $68-100 \%$ answering positively and only $0-7 \%$ negatively. The interactive in-class activities, such as videos, individual thinking/writing exercises, and group discussions were regarded as slightly less useful, but still in majority positive in helping the students understand and learn (Figure 2-3-6). In general, the different years show a similar pattern, with 2016-17 having slightly lower results, probably because the cohort size was $50 \%$ bigger and most changes in assessment were implemented in that year. The largest shift in student perception of usefulness between years happened in the homework tasks (Figure $2-8$ ). The positive answers increased from $48 \%$ in $2015-16$ to $79 \%$ in $2017-18$, and the negative answers decreased from $33 \%$ to $3 \%$. The formative peer-feedback poster session and the session discussing the module assessment (both poster presentation and exam) were both overwhelmingly positive as well, with slightly increasing values between the years (Figure $2-12,13$ ).

\subsection{Module evaluation}

The official module evaluation generally showed positive results (Table 5). Students reported an increase in the work they did for the module and "wider independent study they undertook related to the module" over the years. Students also strongly agreed that the module was "intellectually stimulating" and that it increased their "understanding of the subject", especially in 2017-18. Teaching methods were increasingly regarded as effective, with slightly lower numbers in 2016-17, when most changes to teaching methods and assessment were implemented.

The freetext comments in the official module evaluation mainly had practical suggestions in 2016-17, such as "Please record the lectures" and "3 Minutes for the poster presentation is too short". In 2017-18, there were only a few freetext comments, from students saying that Hydroclimatology was their favourite module.

\subsection{Student feedback}

During the module we collected informal student feedback with post-it notes (Figure 1). Most were used for content-specific feedback, but we also collected some feedback on the coursework. There were many positive general comments, for example: "this is fun" and "I like researching weather events". Students also commented on how the assignments helped them apply theory to real life and learn about a region they were interested in (which for most was their home area). Examples of these type of comments are: "the homework tasks were extremely helpful", "I now know my local soil type!", "I learned about where I live". In 2015-16, there were many comments on 
Table 6. Qualitative student feedback, collected with end-of-teaching questionnaire. Freetext comments were categorised in the analysis, numbers indicate how often a student made a similar comment.

\begin{tabular}{lcc}
\hline What was the most exciting part of the coursework (preparing for the poster & $2016-17$ \\
presentation)? & 5 & $2017-18$ \\
\hline researching own area / finding out things about own area that I did not know & 4 & 9 \\
finding and analysing data / research & 4 & 3 \\
making a water management strategy & - & - \\
following event \& understanding why it happened & - & 8 \\
seeing theory in real life / application of knowledge & $2016-17$ \\
piecing the different bits of information together & 9 \\
\hline What was the most difficult part of the coursework (preparing for the poster & $2017-18$ \\
presentation)? & 2 \\
\hline $\begin{array}{l}\text { finding data / doing practical tasks } \\
\text { linking processes / finding the explanations }\end{array}$ & 11 \\
knowing what to prioritise / focus on, fitting everything on poster and presenta- \\
tion in 3/5min
\end{tabular}

the time constrains for doing the homework tasks (which were still unassessed), e.g.: "I was too busy", "the tasks were too time-consuming", and comments indicating different priorities and preferences: "I would rather read", "does not help me prepare for the exam". Finally there were some comments on practical issues with data collection, such as "difficult when you do not have a garden", "difficult to get data", and "hard to choose what to put on the poster" (in 2016-17).

With the questionnaire we also collected more specific feedback on 'What was the most exciting / most difficult part of the coursework (preparing for the poster presentation)?'. Getting to know more about a familiar area was regarded by many students as the most exciting part of the coursework (Table 6). Many also mentioned doing the research and application of knowledge as positive points. In 2016-17, single students additionally mentioned "infiltration test", "climate / NAO", "hydrology", "synoptic charts", and "seeing it come together". In 2017-18, "soil investigations" and "making the poster", were also mentioned. This shows that students enjoyed a variety of different elements of the coursework.

Students found "fitting everything on the poster and in the short presentation" the most difficult part of the coursework (Table 6). Finding data was difficult for some, especially if their area of interest did not have a gauging station or if website links had changed. Doing the practical tasks was regarded as challenging if the study catchment was located far away from Birmingham.

\subsection{Interviews}

The interviews confirmed in a more comprehensive way the results of the questionnaire, official module evaluation and informal feedback. In Box 2, a few key statements are highlighted. In summary, it seems that both knowing the area and hearing the theory 


\section{BOX 2: INTERVIEW QUOTES}

\section{About the homework tasks:}

- "I don't think I used many of the homework tasks, because I had a few points that I was trying to make in the poster, so it was better to know what they were first and then table what I was doing for that rather than looking back on what we already had been doing, I worked mostly on it at the end" (2016-17)

- "it was helpful the homework tasks" (2016-17)

- "I quite like taking a little sample from home in a little box, doing some tests, it was better than ... you know... than sitting behind a computer, it makes me realise I like Geography more than I think I did" (2016-17)

- "the weekly tasks were useful, but I did the fieldwork tasks over Christmas because it is too far to go back" (2017-18)

About doing the work individually and choosing your own study catchment:

- "if you choose your own area, everyone is doing something different, so you have to go away and find knowledge that is not necessarily covered in the lectures" (2016-17)

- "better than everyone doing the same river, we had presentations before where everyone would present the same thing and that is so dull to watch" (2016-17)

- "with the poster it is easier to design that on your own rather than having to discuss with others, [...] in a group no one really takes responsibility" (2016-17)

- "I liked being able to choose somewhere that you know, it was nice to see different areas in the presentation of others and how the effects change, but I think it would be quite good if you have some background knowledge of the area, you can apply the theory more if you know the area better" (2017-18)

About the poster presentation:

- "that was the challenge of the poster, how you could fit everything onto the poster and into the presentation, so I think it is quite important to limit the time" (2016-17)

- "it is better than an essay, in a presentation you are actually learning it because you actually have to say it, doing a presentation is a key transferable skill" (2016-17)

- "I'd never done an academic poster before, learning how to structure a poster was useful, in my formative draft poster everything was all over the place, I learnt to filter important information and what to put first" (2017-18)

About the open-endedness of the assignment:

- "much closer to doing a dissertation than what we'd done in first year without being too open-ended, it was nice, good preparation" (2016-17)

- "if it [preparation for the dissertation research project] wasn't done in the 2nd year, when would it be done?" (2016-17)

About link with the lectures:

- "there could have been a closer link with the lectures, it was there but could be closer" (2016-17)

- "if you choose your own area, everyone is doing something different, so you have to go away and find knowledge that is not necessarily covered in the lectures" (2016-17)

- "there was a good link between the lectures and what I saw in the catchment" (2017-18)

- "you needed to figure out what bits of the lecture best fitted to your river, from the lectures you were able to understand how your river works, you can be like: oh, that is why that area flooded" (2017-18)

About recommending the module to next year's students:

- "I just liked that it was different to things we were doing in other modules, but that is probably down to my module choice" (2016-17)

- "I would do it again and would recommend to next year's students" (2017-18) 
in the lectures helped the students in the research project to understand the processes in their study catchment and that understanding subsequently helped (some of) them in the exam. Looking back on the module after doing their dissertation, the 2016-17 students report that doing an individual research project that was not organised like a "cookbook" was useful preparation for their dissertation project. In general, they enjoyed the fieldwork, they liked learning about their own area, and it made them enjoy geography more. Most students also realised that the skills they learned for filtering information and presenting only the most important aspects are actually quite useful.

This quote from a 2017-18 student nicely summarises the student perspective on the coursework:

"Fieldwork helps linking lectures to real life, you can apply it, it also helped with the exam, because if there was an example that was linked to your area you could remember it much better, and it will be useful for my summer job which is on the river."

\subsection{Lecturer evaluation}

All three lecturers on the module (including myself) were positive about the changes in assessment in general. One lecturer noted that the poster assessment forced the students to "be more creative, to do something constructive, instead of just answering a question and being completely responsive". We also agreed that individual projects were better than group projects, because it allows students to take ownership of the work. One lecturer commented that "it is good for the good students, because they can show what they can do and it might be very motivating. And for the not so good ones, it may also help their self-reflection, because they cannot blame it on the group." This was also helpful for the marking, with the individual poster presentations "showing evidence of what the student can do".

There was a difference in how much lecturers changed their lectures in line with the changes in assessment. I have made changes in my lectures over the years to link the theory with the homework tasks and the poster assessment. For example, after discussing the theory of soil moisture in different soil types I would mention internet sources and apps for students to find information about the soil type of their study areas. And in the next lecture I would allow time for questions about the homework and would discuss generic patterns in the homework tasks (the distribution of soil types in the UK). The other lecturers did not make many changes to what they did in class. One of them just mentioned the homework tasks during the lecture. The other lecturer mentioned that he not really changed what he did in class: "I have to go through my stuff and I'm usually short of time. I answered the occasional question about data availability, things like that." But he added that he would consider making changes in the future: "It's an interesting thought. In the future I hope to make more time for discussion so that the lecture content could be linked to the homework assignments."

There were also differences in the lecturers' assessment of student engagement. I myself noticed from the interaction in class that students were much more engaged with the material in 2016-17 and 2017-18, with the poster assessment of homework assignments, than in 2015-16, when the homework tasks were unassessed. One other lecturer found it hard to tell whether students were more engaged when the homework tasks were introduced, because "in a lecture students are just sitting there, listening. They maybe more engaged, but it was not bluntly obvious in the lectures". He did think, however, that students might engage with the material sooner, because they need to understand it already for the poster session, which is before the exam revision 
period. The other lecturer noticed that "this year (2017-18) in the peer-feedback session the draft posters were closer to the finished product than the year before (2016-17)." The formative assessment poster session with peer-feedback was attended only by a little over half of the students in both years, but was valued by those students present and by the lecturers. It gave us the opportunity to gauge how they were doing and students could compare their work to their peers and to the lecturers' expectations.

The lecturers noted as well that marks did not significantly increase over the years. The module still has a negative bias in the marks compared to student's other marks. One lecturer thinks that the reason for that is that it is a science module that geography students tend to struggle with in general: "you cannot waffle your way through." For the marking of the poster presentation, all agreed that it was helpful to have a teaching assistant (PhD student) to organise the poster session and to serve as sounding board for the markers.

\section{Discussion}

In this research, information from different sources and different perspectives was combined. Limitations are that the numbers were quite small (Tables 1 and 2) and not always representative (e.g. the interviewees' gender, Sect. 5.4), and that learning gain has not been investigated, for example with pre and post tests (Arthurs \& Templeton, 2009). Therefore, the effectiveness of the change in teaching method on student learning cannot be quantified. Nevertheless, the qualitative evaluation gives a comprehensive overview of student and lecturer perspectives on the use of individual student projects complementing lectures in an undergraduate module in physical geography.

The open-ended assignment requires the students to do a 'triangulation' of knowledge (Bogdan \& Biklen, 2007), coupling their data collection and analysis results to their prior knowledge of the area and their theoretical understanding of hydroclimatological processes. This corresponds to the educational theory of constructivism, which posits that learners learn best if they make connections between new information and prior knowledge (Thompson et al., 2012). Students commented extensively on this both in the questionnaire (Sect. 5.3, Table 6) and in the interviews (Sect. 5.6, Box 2).

The assignment gave students ownership of their project, which was regarded as positive by students and lecturers, as transpired from the interviews (Sect. 5.6 and 5.7, Box 2). Research on student-led fieldwork reported similar positive aspects of ownership (Kneale, 1996; Pawson \& Teather, 2002). The setup allows for students to develop their own learning and be creative in their research project, which is exemplified by one student calculating the rating curve based on historic data to convert the recent water level observations to discharge. It is encouraging to see that students found the assignment useful for their dissertation (Sect. 5.6, Box 2), which had not been mentioned by the lecturers as an objective of the coursework and is a good sign of empowerment (Hill \& Woodland, 2002).

By letting students choose their own case study in an area they are familiar with we also draw on motivational and affective processes which have been found to contribute significantly to student learning (Thompson et al., 2012). Students noted in the informal feedback and in the interviews that they enjoyed doing their projects and learning something new about their area (see Sect. 5.5 and 5.6). Lecturers also noted that the projects made them more enthusiastic about the topic and more engaged with the material (Sect. 5.7). According to Bloom et al. (1956) this emotional domain is an 
important part of education.

Student engagement is one of the most important drivers of learning (Biggs \& Tang, 2011) and is positively linked with critical thinking skills and marks (Carini, Kuh, \& Klein, 2006). A possible measure of engagement is the time students spend on doing the work, which in our case increased significantly over the years (Sect. 5.1, Table 3). It is known that if students spend more time preparing for an assessment they are likely to perform better (Howard, 2015; Walker, 2005). As mentioned in the literature, assessment is an important driver of student activity (Biggs \& Tang, 2011; Gibbs \& Simpson, 2005), which corresponds to the findings in this study that students spend more time (Table 3), are more engaged (Sect. 5.7), and value homework tasks more for their understanding of the topic (Sect. 5.5, Fig. 2) when they were assessed. The formative assessment had a similar effect (Sect. 5.7) and was regarded as very useful by the students (Fig. 2), at least by those that attended the session and prepared for it.

Coursework marks were higher than exam marks, which corresponds to a general trend observed by Bridges et al. (2002), Yorke, Bridges, and Woolf (2000), and Gibbs and Simpson (2004). The reasons for this difference are still under debate, but in this case I think it probably reflects the amount of work that most students put into the preparation for the coursework and the deeper learning that takes place when doing the individual projects. We had expected the exam marks to increase when we introduced the coursework (like Kingston et al., 2012; López-Pérez, Pérez-López, \& Rodríguez-Ariza, 2011), assuming that after seeing the application of the theory in the field students would understand the theory better. This has not been the case yet with 2017-18 marks comparable to $2015-16$, but it might be too early to see the effect, staff and students both needing some time to adjust to the changes in module assessment.

Compared to a traditional lecture or field course, our setup combines the benefits of students doing their own measurements and using online resources. Doing measurements gives students an understanding of the difficulties, uncertainties and representativity of the measurements (Table 6), which cannot be obtained from virtual field tours (Kingston et al., 2012) or case studies of exotic locations (King et al., 2012). Using online resources familiarises students with issues around data availability (Sect. 5.5), temporal and spatial scales and resolution of data, and information used in management decisions (King et al., 2012).

Letting students work on their local area as case study also automatically makes students study the effect of human activities on hydrological processes, which is very much missing from hydrology education according to King et al. (2012). Some students, for example, decided to focus their analysis on the effects of urbanisation on the rainfall-runoff relationship, without this being mentioned as an option by the lecturers. Most hydrology lectures and field courses focus on natural processes, but hydrology graduates increasingly need to understand the dynamic interactions between water and society (King et al., 2012; Ruddell \& Wagener, 2013), which would make them much better equipped to solve complex social-environmental problems both in science and in practice (King et al., 2012; Van Loon et al., 2016; Wagener et al., 2010).

The questionnaire results show that students value the traditional lecture most in helping them learn (Sect. 5.3, Fig. 2). This has been found in other studies as well (e.g., Arthurs \& Templeton, 2009; Mitchell \& Forer, 2010; Yadav et al., 2011). Yadav et al. (2011) showed that students value lectures higher than project-based learning even when independent analysis showed that they had learned more from the projectbased learning. The most obvious reason for this preference might be that sitting in lectures and listening to a lecturer is easier than collecting and interpreting your own 
data (Sect. 5.5) and students are more used to this type of teaching (Box 2). Arthurs and Templeton (2009) attribute students' preference for lectures to 1) the quality of the lectures and lecturers (also noted by Mitchell \& Forer, 2010), 2) the fact that 50\% of the final grade was determined from an exam that covered lecture material (which is the same in our module, Sect. 3.3), and 3) the close link between lecture, in-class activities and homework tasks, making it hard to disentangle to benefit of each of them separately. In our case this last aspect, the link between the lectures and the homework project, could still be improved (Sect. 5.6, Box 2). Highest learning gains are expected when homework is coupled to in-class activities (Arthurs \& Templeton, 2009), which in our case study was lecturer-dependent (Sect. 5.7). Spronken-Smith (2005) and Spronken-Smith and Harland (2009) also noted that teachers have different ways of implementing active learning methods and many reported difficulties in transitioning, despite overall enthusiasm. A change from lecturer-centred to student-centred teaching requires willingness and ability from both teachers and students. In previous studies, students have been found to struggle in making connections between the lectures and field-based activities themselves (Hill \& Woodland, 2002) and a change to studentcentred teaching methods requires change in student attitude (Thompson et al., 2012).

Based on this study there seems to be many benefits for students in doing their projects individually, instead of in a group. In the interviews, lecturers and students mentioned several positive aspects: 1) ownership of the project, 2) choosing an area they are familiar with, and 3) not having to discuss the poster presentation with a group (Sect. 5.7 and 5.6). Interestingly, students did value the opportunity to see each other's projects in the poster session and mentioned that it helped their understanding of the differences in hydroclimatology between catchments (Box 2). Thompson et al. (2012) mention that studying the similarities and differences between geographic areas is a very important element in hydrology education. This makes the poster assessment more useful for learning than an individual essay that only the lecturer reads.

The poster assessment has also proven to be beneficial for development of skills in ranking knowledge in terms of its importance and organising it by its usefulness to answer a certain research question. The questionnaires (Sect. 5.3, Table 6) showed that these were the aspect that students struggled with most, but in the interviews (Sect. 5.6, Box 2) students indicated that looking back they see the value of learning how to filter information. The poster assessment also allows for creativity in terms of presentation. For example, one student brought soil samples to class and another included a animation of synoptic charts on the poster (which was possible because we used electronic posters in Powerpoint instead of printed posters). In the marking of the poster presentations we gave credit to these students who went beyond the assignment and presented their results creatively (Box 1: 80-100\% range).

The comparison between the years has shown that adding active learning components to the teaching and assessment methods has many merits. Although the effects of purely project-based teaching and assessment were not investigated, it can be hypothesised that the more direct link between theory (in lectures) and application (in the homework-based projects) supports student learning more than separate field courses or projects (Fuller et al., 2000). In the interviews, the students mentioned that they see the lectures as useful for the homework ('from the lectures you were able to see how your river works', Box 2) and the homework as useful for the exam ('if there was an example that was linked to your area you could remember it much better', Sect. 5.6). Other scholars have also found that the integration of theory and application increases deep learning (Edelson, 2001) and argued that student- and lecturer-centered approaches should be used in combination (Gleeson et al., 2012; Thompson et al., 
2012). Dorsey (2001) successfully implemented a combination of theoretical lectures and service-learning projects and Trop et al. (2000) and Noll (2003) integrated field observations and lab work. Others suggest a range of active learning activities to complement lectures, both in-class (e.g. flash cards, case study projects, student reflection, writing assignments, and interactive discussions; Cutrim et al. (2006)) and after class (real world projects, homework, experiments, model development, talking to experts, and group projects; Bernold, Bingham, McDonald, and Attia (2000)). Complementing lectures with homework-based individual research projects is relatively easy to implement and does not require much lecturer time investment besides the design of the assignment. Important aspects are that the lectures and assessment are adapted accordingly.

\section{Conclusions}

Changes in teaching methods and assessment were implemented in a undergraduate geography module on Hydroclimatology to stimulate active learning and the link between the classroom and the outside world. Changes have been evaluated over a 3-year implementation period. From a combination of formal and informal student and lecturer feedback it was found that students enjoyed doing the individual homework-based project and that it helped their understanding of the theory, their research skills, and their ability to select, organise and present information.

The new assessment makes students more enthusiastic about the subject, more engaged with the material, and it prepares students better for follow-up modules, their dissertation and for a job as geography graduate. The change also spreads out the workload for students and markers over the year and hopefully makes the assessment more inclusive and fairer for different types of students. The increased guidance, formative assessment, and feedback gives students more opportunities to practise and to gauge how they are progressing.

It can be noted that the informal student feedback, the results from the targeted questionnaire, and the interviews with students and lecturers gave much more insight into the merits of the active learning approaches than the standard module evaluation results. The generic questions in the standard module evaluation do not provide enough detailed information specific to the project.

With this paper I hope to have contributed to the educational literature on studentcentred approaches in hydrology and inspired my physical geography colleagues to experiment with different teaching methods. The more colleagues become aware of the options and their effectiveness, the more we can move away from only traditional lecture formats to a format integrating active-learning elements in-class and between classes, linking the classroom to the outside world, which is more suited to the complexities of real world (hydrological) challenges.

\section{Acknowledgements}

I thank my colleagues Martin Widmann and Ian Phillips for being convinced by my plea for changing the module's teaching method and assessment, and for helping with the implementation of the changes. I also thank the Hydroclimatology students of the 2015-16, 2016-17 and 2017-18 classes for their invaluable feedback on the changes. Thanks to Kay West, for providing the data in Table 1 and for general support of 
the module, and to the PhD students Danny Croghan, Doris Wendt, Colin Manning, Lucinda Capewell, and Julia Docherty for helping with the poster sessions.

This work benefited from discussions with colleagues at the EGU conference and the PCAP training. I specifically want to mention Claudia Brauer (Wageningen University, the Netherlands) for her excellent ideas of student-centred teaching methods, Jan Seibert (University of Zurich, Switzerland) and Lena Tallaksen (University of Oslo, Norway) for inspiring discussions on innovations in hydrology education, and Mel Rohse (Anglia Ruskin University, UK) for indispensable support on the social science aspects of this research.

I'm also thankful for the supportive writing environment provided by the GEES writing week in July 2018 and for proof-reading done by Henk Krajenbrink. The feedback of the editor and two anonymous reviewers has improved the paper.

\section{Disclosure statement}

No potential conflict of interest is reported by the author.

\section{References}

Aghakouchak, A., \& Habib, E. (2010). Application of a conceptual hydrologic model in teaching hydrologic processes.

Arthurs, L., \& Templeton, A. (2009). Coupled collaborative in-class activities and individual follow-up homework promote interactive engagement and improve student learning outcomes in a college-level environmental geology course. Journal of Geoscience Education, $57(5), 356-371$.

Assaraf, O. B.-Z., \& Orion, N. (2005). Development of system thinking skills in the context of earth system education. Journal of Research in Science Teaching: The Official Journal of the National Association for Research in Science Teaching, 42(5), 518-560.

Beringer, J. (2007). Application of problem based learning through research investigation. Journal of Geography in Higher Education, 31 (3), 445-457.

Bernold, L., Bingham, W., McDonald, P., \& Attia, T. (2000). Impact of holistic and learningoriented teaching on academic success. Journal of Engineering Education, 89(2), 191-200.

Biggs, J. (1996). Enhancing teaching through constructive alignment. Higher education, 32 (3), $347-364$

Biggs, J. (1999). What the student does: teaching for enhanced learning. Higher Education Research \& Development, 18(1), 57-75.

Biggs, J., \& Tang, C. (2011). Teaching for quality learning at university: What the student does. McGraw-Hill Education (UK).

Bloom, B. S., et al. (1956). Taxonomy of educational objectives. vol. 1: Cognitive domain. New York: McKay, 20-24.

Bogdan, R., \& Biklen, S. (2007). Qualitative research for education: An introduction to theory and practice. Needham Heights, MA: Allyn and Bacon.

Bridges, P., Cooper, A., Evanson, P., Haines, C., Jenkins, D., Scurry, D., .. Yorke, M. (2002). Coursework marks high, examination marks low: discuss. Assessment 83 Evaluation in Higher Education, 27(1), 35-48.

Buckley, G. L., Bain, N. R., Luginbuhl, A. M., \& Dyer, M. L. (2004). Adding an active learning component to a large lecture course. Journal of Geography, 103(6), 231-237.

Carini, R. M., Kuh, G. D., \& Klein, S. P. (2006). Student engagement and student learning: Testing the linkages. Research in higher education, 47(1), 1-32. 
Coe, N. M., \& Smyth, F. M. (2010). Students as tour guides: Innovation in fieldwork assessment. Journal of Geography in Higher Education, 34(1), 125-139.

Cutrim, E., Rudge, D., Kits, K., Mitchell, J., \& Nogueira, R. (2006). Changing teaching techniques and adapting new technologies to improve student learning in an introductory meteorology and climate course. Advances in Geosciences, 8, 11-18.

Dochy, F., Segers, M., \& Sluijsmans, D. (1999). The use of self-, peer and co-assessment in higher education: A review. Studies in Higher education, 24 (3), 331-350.

Dochy, F., Segers, M., Van den Bossche, P., \& Gijbels, D. (2003). Effects of problem-based learning: A meta-analysis. Learning and instruction, 13(5), 533-568.

Dorsey, B. (2001). Linking theories of service-learning and undergraduate geography education. Journal of Geography, 100(3), 124-132.

Drever, E. (1995). Using semi-structured interviews in small-scale research. a teacher's guide. ERIC.

Edelson, D. C. (2001). Learning-for-use: A framework for the design of technology-supported inquiry activities. Journal of Research in Science teaching, 38(3), 355-385.

Elshorbagy, A. (2005). Learner-centered approach to teaching watershed hydrology using system dynamics. International Journal of Engineering Education, 21 (6), 1203.

Fuller, I., Edmondson, S., France, D., Higgitt, D., \& Ratinen, I. (2006). International perspectives on the effectiveness of geography fieldwork for learning. Journal of Geography in Higher Education, 30(1), 89-101.

Fuller, I., Rawlinson, S., \& Bevan, R. (2000). Evaluation of student learning experiences in physical geography fieldwork: Paddling or pedagogy? Journal of Geography in Higher Education, 24(2), 199-215.

Gibbs, G. (2014). Lectures are used far too often, in: 53 powerful ideas all teachers should know about, seda supporting and leading educational change, www.seda.ac.uk [last access: 5-6-2015].

Gibbs, G., \& Simpson, C. (2004). Does your assessment support your students learning. Journal of Teaching and learning in Higher Education, 1(1), 1-30.

Gibbs, G., \& Simpson, C. (2005). Conditions under which assessment supports students learning. Learning and teaching in higher education(1), 3-31.

Gijbels, D., Dochy, F., Van den Bossche, P., \& Segers, M. (2005). Effects of problem-based learning: A meta-analysis from the angle of assessment. Review of educational research, $75(1), 27-61$.

Gleeson, T., Allen, D., \& Ferguson, G. (2012). Teaching hydrogeology: a review of current practice. Hydrology and Earth System Sciences, 16(7), 2159-2168.

Goris, T. V., \& Dyrenfurth, M. J. (2012). Concepts and misconceptions in engineering, technology and science. overview of research literature. In Proc. amer. soc. eng. educ. il/in sectional conf.

Haigh, M., \& Gold, J. R. (1993). The problems with fieldwork: a group-based approach towards integrating fieldwork into the undergraduate geography curriculum. Journal of Geography in Higher Education, 17(1), 21-32.

Hakoun, V., Mazzilli, N., Pistre, S., \& Jourde, H. (2013). Teaching groundwater flow processes: connecting lecture to practical and field classes. Hydrology and Earth System Sciences, $17(5), 1975-1984$.

Handelsman, J., Miller, S., \& Pfund, C. (2007). Scientific teaching. Macmillan.

Hay, I., \& Miller, R. (1992). Application of a poster exercise in an advanced undergraduate geography course. Journal of Geography in Higher Education, 16(2), 199-215.

Hay, I., \& Thomas, S. M. (1999). Making sense with posters in biological science education. Journal of Biological Education, 33(4), 209-214.

Healey, M., Matthews, H., Livingstone, I., \& Foster, I. (1996). Learning in small groups in university geography courses: Designing a core module around group projects. Journal of Geography in Higher Education, 20(2), 167-180.

Henderson, J., Bellman, L., \& Furman, B. (1983). A case for teaching-engineering with cases. Engineering Education, 73(4), 288-292. 
Hill, J., \& Woodland, W. (2002). An evaluation of foreign fieldwork in promoting deep learning: A preliminary investigation. Assessment 8 Evaluation in Higher Education, 27(6), 539555 .

Hoag, K., Lillie, J., \& Hoppe, R. (2005). Piloting case-based instruction in a didactic clinical immunology course. Clinical Laboratory Science, 18(4), 213.

Howard, C. (2015). The role of posters as a means of summative assessment. Worcester Journal of Teaching and Learning(10).

Jarvis, L., \& Cain, J. (2003). Posters and oral presentations in undergraduate history of science. Discourse: Learning and Teaching in Philosophical and Religious Studies, 2(2), $50-72$.

Kastens, K. A., \& Manduca, C. A. (2012). Earth and mind ii: A synthesis of research on thinking and learning in the geosciences (Vol. 486). Geological Society of America.

Kent, M., Gilbertson, D. D., \& Hunt, C. O. (1997). Fieldwork in geography teaching: A critical review of the literature and approaches. Journal of geography in higher education, 21(3), 313-332.

King, E., O’Donnell, F., \& Caylor, K. (2012). Reframing hydrology education to solve coupled human and environmental problems. Hydrology and Earth System Sciences, 16(11), 40234031.

Kingston, D., Eastwood, W., Jones, P., Johnson, R., Marshall, S., \& Hannah, D. (2012). Experiences of using mobile technologies and virtual field tours in physical geography: implications for hydrology education. Hydrology and Earth System Sciences, 16 (5), 1281-1286.

Kneale, P. (1996). Organising student-centred group fieldwork and presentations. Journal of Geography in Higher Education, 20(1), 65-74.

Kolb, D. (1984). Experiential education: Experience as the source of learning and development. Englewood Cliffs, NJ.

Krakowka, A. R. (2012). Field trips as valuable learning experiences in geography courses. Journal of Geography, 111(6), 236-244.

Laird, T. F. N., Shoup, R., Kuh, G. D., \& Schwarz, M. J. (2008). The effects of discipline on deep approaches to student learning and college outcomes. Research in Higher Education, 49(6), 469-494.

López-Pérez, M. V., Pérez-López, M. C., \& Rodríguez-Ariza, L. (2011). Blended learning in higher education: Students perceptions and their relation to outcomes. Computers \& education, 56(3), 818-826.

Mills, J. E., Treagust, D. F., et al. (2003). Engineering educationis problem-based or projectbased learning the answer. Australasian journal of engineering education, 3(2), 2-16.

Mitchell, P., \& Forer, P. (2010). Blended learning: The perceptions of first-year geography students. Journal of Geography in Higher Education, 34(1), 77-89.

Noll, M. R. (2003). Building bridges between field and laboratory studies in an undergraduate groundwater course. Journal of Geoscience Education, 51(2), 231-236.

Oliver, C., Leader, S., \& Kettridge, N. (2018). Birmingham bog outdoor laboratory: potentials and possibilities for embedding field-based teaching within the undergraduate classroom. Journal of Geography in Higher Education, 42(3), 442-459. Retrieved from https://doi .org/10.1080/03098265.2018.1455816

Pathirana, A., Koster, J., Jong, E. d., \& Uhlenbrook, S. (2012). On teaching styles of water educators and the impact of didactic training. Hydrology and Earth System Sciences, 16 (10), $3677-3688$.

Pawson, E., \& Teather, E. K. (2002). 'geographical expeditions': Assessing the benefits of a student-driven fieldwork method. Journal of Geography in Higher Education, 26 (3), 275289.

Prince, M. J., \& Felder, R. M. (2006). Inductive teaching and learning methods: Definitions, comparisons, and research bases. Journal of engineering education, 95 (2), 123-138.

Race, P. (2014). Making learning happen: A guide for post-compulsory education. Sage.

Roebber, P. J. (2005). Bridging the gap between theory and applications: An inquiry into atmospheric science teaching. Bulletin of the American Meteorological Society, 86(4), 507- 
518.

Ruddell, B. L., \& Wagener, T. (2013). Grand challenges for hydrology education in the 21st century. Journal of Hydrologic Engineering, 20(1), A4014001.

Rustum, R. (2018). Teaching hydrology: A case study of teaching and learning. In Advances in science and engineering technology international conferences (aset), 2018 (pp. 1-3).

Seibert, J., \& Vis, M. J. P. (2012). Teaching hydrological modeling with a user-friendly catchment-runoff-model software package. Hydrology and Earth System Sciences, 16(9), $3315-3325$.

Spronken-Smith, R. (2005). Implementing a problem-based learning approach for teaching research methods in geography. Journal of Geography in Higher Education, 29(2), 203-221.

Spronken-Smith, R., \& Harland, T. (2009). Learning to teach with problem-based learning. Active Learning in Higher Education, 10(2), 138-153.

Stainfield, J., Fisher, P., Ford, B., \& Solem, M. (2000). International virtual field trips: a new direction? Journal of Geography in Higher Education, 24 (2), 255-262.

Thompson, S. E., Ngambeki, I., Troch, P. A., Sivapalan, M., \& Evangelou, D. (2012). Incorporating student-centered approaches into catchment hydrology teaching: a review and synthesis. Hydrology and Earth System Sciences, 16(9), 3263-3278.

Trop, J. M., Krockover, G. H., \& Ridgway, K. D. (2000). Integration of field observations with laboratory modeling for understanding hydrologic processes in an undergraduate earthscience course. Journal of Geoscience Education, 48(4), 514-521.

Van Loon, A. F., Gleeson, T., Clark, J., Van Dijk, A. I., Stahl, K., Hannaford, J., ... others (2016). Drought in the anthropocene. Nature Geoscience, 9(2), 89.

Wagener, T., Sivapalan, M., Troch, P. A., McGlynn, B. L., Harman, C. J., Gupta, H. V., ... Wilson, J. S. (2010). The future of hydrology: An evolving science for a changing world. Water Resources Research, 46(5).

Walker, S. (2005). Poster poster on the wall: whose is the fairest assessment of all? Journal of family therapy, 27(3), 285-288.

Woods, D. R., Felder, R. M., Rugarcia, A., \& Stice, J. E. (2000). The future of engineering education iii. developing critical skills. change, 4, 48-52.

Yadav, A., \& Beckerman, J. L. (2009). Implementing case studies in a plant pathology course: Impact on student learning and engagement. A Collection of Case Studies(casestudies), $100-105$.

Yadav, A., Shaver, G. M., \& Meckl, P. (2010). Lessons learned: Implementing the case teaching method in a mechanical engineering course. Journal of Engineering Education, 99(1), 55-69.

Yadav, A., Subedi, D., Lundeberg, M. A., \& Bunting, C. F. (2011). Problem-based learning: Influence on students' learning in an electrical engineering course. Journal of Engineering Education, $100(2), 253-280$.

Yorke, M., Bridges, P., \& Woolf, H. (2000). Mark distributions and marking practices in uk higher education: some challenging issues. Active learning in higher education, 1(1), 7-27. 
Appendix A. Example student poster 

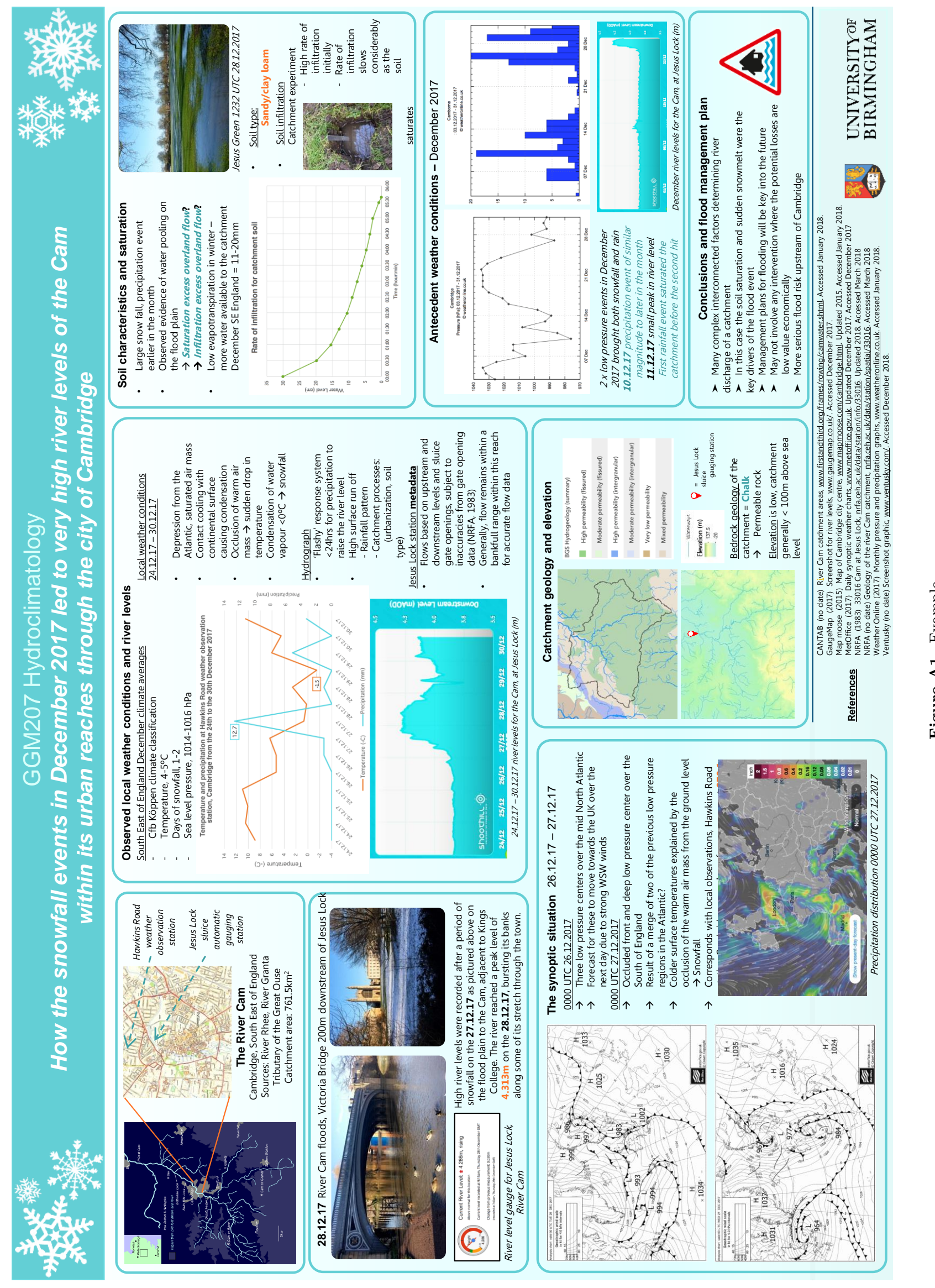
This is an EarthArXiv preprint, accepted by the Journal of Geography in Higher Education.

Appendix B. Questionnaire 


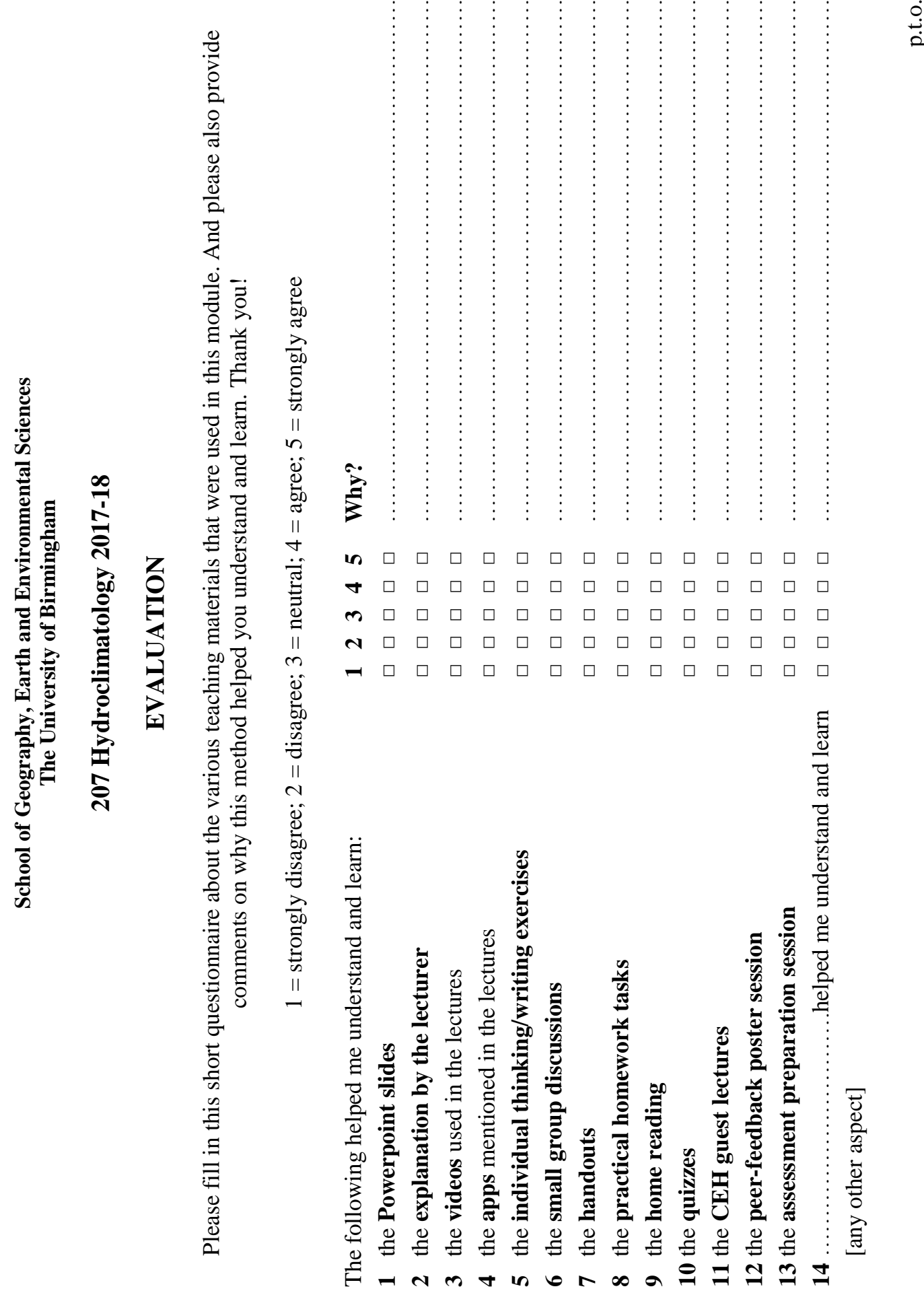




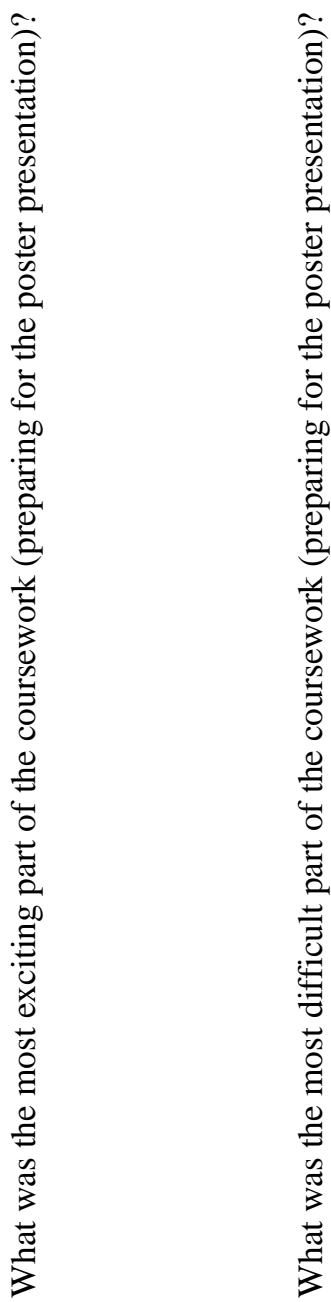

